\title{
PENGARUH MOTIVASI BELAJAR, GAYA BELAJAR, DAN KEMANDIRIAN BELAJAR TERHADAP HASIL BELAJAR MAHASISWA S1 PGSD MASUKAN SARJANA DI UPBJJ UT BANDUNG Oleh:

\author{
Rasdjo Dedi $\mathbf{S}^{1}$, Angga Sucitra Hendrayana ${ }^{2}$, Erin Erisyani ${ }^{3}$, Nana Setiana ${ }^{4}$ \\ UPBJJ- UT Bandung
}

\begin{abstract}
At the college level, students are the ones who are following the course of education has hope of success for the sake of his future studies. As one satutolok measuring student success is the high value obtained is calculated by the average value called Index Point Average (GPA) .Many factors affecting contribution to the achievement of the GPA student, one motivation belajar.Gaya learn to be one of the factors that can indeksprestasi cumulative affect students. In this case also included the learning style of teaching aids trivial factor. Learning on distance learning system are the basic principles of education at the Open University (UT) requires learners, learning activities independently. Such activity requires the learners, learning independence. Independent learning is the readiness of individuals who are willing and able to learn on their own initiative, with or without the help of others in terms of learning objectives, learning methods, and evaluation of learning outcomes. The sample in this study is 162 Degree Feedback SIPGSD student. From the research results can be found in learning motivation, learning styles, learning independence, an effect on learning outcomes
\end{abstract}

Keywords: Motivation, Learning Styles, independence Learning, Learning Outcomes

\begin{abstract}
Abstrak: Pada tingkat perguruan tinggi mahasiswa adalah orang-orang yang sedang mengikuti pendidikan tentunya mempunyai harapan akan keberhasilan studi demi masa depannya. Sebagai salah satutolok ukur keberhasilan mahasiswa adalah nilai yang diperolehnya adalah tinggi yang dihitung dengan nilai ratarata disebut Indek Prestasi Kumulatif (IPK).Banyak faktor yang mempengaruhi kontribusi terhadap pencapaian Indeks Prestasi Kumulatif mahasiswa, salah satunya motivasi belajar.Gaya belajar menjadi salah satu faktor yang dapat mempengaruhi indeksprestasi kumulatif mahasiswa. Dalam hal ini gaya belajar juga termasuk faktor penunjang belajar yang pentig. Pembelajaran pada sistem belajar jarak jauh yang merupakan prinsip dasar pendidikan di Universitas Terbuka (UT) mengharuskan peserta ajar melakukan aktivitas belajar secara mandiri. Aktivitas tersebut mempersyaratkan kemandirian belajar pada peserta ajar. Kemandirian belajar merupakan kesiapan dari individu yang mau dan mampu untuk belajar dengan inisiatif sendiri, dengan atau tanpa bantuan pihak lain dalam hal penentuan tujuan belajar, metoda belajar, dan evaluasi hasil belajar. Sampel dalam penelitian ini adalah 162 mahasiswa S1PGSD Masukan Sarjana. Dari hasil penelitian di dapat bahwa motivasi belajar, gaya belajar, kemandirian belajar, berpengaruh terhadap hasil belajar
\end{abstract}

Kata Kunci: Motivasi Belajar, Gaya Belajar, kemandirian Belajar, Hasil Belajar

\section{PENDAHULUAN}

Berdasarkan UU nomor 14 tahun 2005 tentang Guru dan Dosen pasal 10 ayat (1), serta PP nomor 32 tahun 2013 tentang Standar Nasional Pendidikan dan kompetensi guru meliputi kompetensi

\footnotetext{
${ }^{1}$ UPBJJ-UT Bandung, Email: Rasdjods@ut.ac.id

2 UPBJJ-UT Bandung, Email: angga-sucitra@ut.ac.id,

3 UPBJJ-UT Bandung, Email: erin@ut.ac.id

${ }^{4}$ UPBJJ-UT Bandung, Email: nana-setiana@ut.ac.id
}

pedagogik, kompetensi kepribadian, kompetensi profesional, dan kompetensi sosial. Namun demikian, dalam hal kompetensi guru yang diharapkan, khususnya guru SD, masih ada diantara mereka yang teah bergelar sarjana tetapi 
kompetensi gelar kesarjanaan yang diperoleh beleum relevan dengan tugas keseharian mereka sebagai guru SD.

Dalam upaya memberikan alternatif untuk menyelesaikan permasalahan tersebut maka Fakultas Keguruan dan IlmuPendidikan Universitas Terbuka (FKIP - UT) membuka kesempatan bagi guru dalam jabatan yang berlatar belaang S1 dari berbagai disiplin ilmu untuk mengikuti program pendidikan S1 PGSD.

Dalam sistem pembelajarannya, UT menerapkan sistem belajar jarak jauh dan terbuka. Istilah jarak jauh berarti pembelajaran tidak dilakukan secara tatap muka, melainkan menggunakan media, baik media cetak (modul) maupun noncetak (audio/video, komputer/internet, siaran radio dan televisi). Makna terbuka adalah tidak ada pembatasan usia, tahun ijazah, masa belajar, waktu registrasi, dan frekuensi mengikuti ujian. Batasan yang ada hanyalah bahwa setiap mahasiswa UT harus sudah menamatkan jenjang pendidikan menengah atas yaitu SMA atau yang sederajat.

Dalam hal cara belajar, mahasiswa UT diharapkan dapat belajar secara mandiri. Cara belajar mandiri menghendaki mahasiswa untuk belajar atas prakarsa atau inisiatif sendiri. Belajar mandiri dapat dilakukan secara sendiri ataupun berkelompok, baik dalam kelompok belajar maupun dalam kelompok tutorial. UT menyediakan bahan ajar yang dibuat khusus untuk dapat dipelajari secara mandiri.

Pada tingkat perguruan tinggi mahasiswa adalah orang-orang yang sedang mengikuti pendidikan tentunya mempunyai harapan akan keberhasilan studi demi masa depannya. Sebagai salah satutolak ukur keberhasilan mahasiswa adalah nilai yang diperolehnya adalah tinggi yang dihitung dengan nilai ratarata disebut Indek Prestasi Kumulatif (IPK). Indeks prestasi kumulatif merupakan angka yang menunjukkan prestasi atau kemajuan belajar mahasiswa secara kumulatif mulai dari semester pertama sampai dengan semester paling akhir yang telah ditempuh (Susanti \& Nadziruddin, 2007).

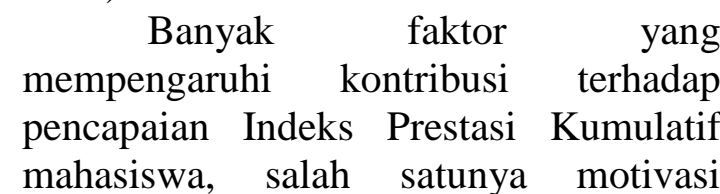
belajar. Motivasi belajar sangat berperan penting dalam proses belajar dikarenakan proses belajar membutuhkan interaksi dan partisipasi aktif dari para pembelajar untuk berhasil (Saputra, dalam Setiabudi, 2007).

Gaya belajar menjadi salah satu faktor yang dapat mempengaruhi indeksprestasi kumulatif mahasiswa. Dalam hal ini gaya belajar juga termasuk faktor penunjang belajar yang penting. Gaya belajar merupakan kombinasi dari bagaimana seseorang menyerap, mengatur dan mengolah informasi (DePorter, dalam Pranata, 2002). Gaya belajar juga memiliki beberapa variabel antara lain faktor persepsi dan pemrosesan informasi, faktor motivasi, dan faktorpsikologi.

Pembelajaran pada sistem belajar jarak jauh yang merupakan prinsip dasar pendidikan di Universitas Terbuka (UT) mengharuskan peserta ajar melakukan aktivitas belajar secara mandiri. Aktivitas tersebut mempersyaratkan kemandirian belajar pada peserta ajar. Menurut Long (1989), kemandirian belajar hanya ditujukan kepada orang dewasa (andragogi) (dalam Irzan tahar dan Encang).

\section{TINJAUAN TEORETIS Motivasi Belajar}

Dalam bahasa latin motivasi disebut juga movere, yang berarti bergerak (move) yang artinya motivasi berasal dari kata motif yang artinya dorongan yang datang dari dalam untuk berbuat.Motivasi menjelaskan apa yang membuat orang melakukan sesuatu, 
membuat mereka tetap melakukannya, dan membantu mereka dalam menyelesaikan tugas-tugas. Hal ini berarti bahwa konsep motivasi digunakan untuk menjelaskan keinginan berperilaku, arah perilaku (pilihan), intensitas perilaku (usaha, berkelanjutan), dan penyelesaian atau prestasi yang sesungguhnya (Pintrich, 2003).Karena itu motif diartika sebagai kekuatan yang terdapat dalam diri organisme yang mendorong untuk berbuat atau merupakan driving force (Walgito \& Bimo, 2004).

Sunaryo (2004) menyebutkan bahwa ada beberapa cara yangdapat diterapkan untuk memotivasi seseorang yaitu :

a. Memotivasi dengan kekerasan (motivating by force)Yaitu dengan cara memotivasi dengan menggunakan ancamanhukuman atau kekerasan agar yang dimotivasi dapat melakukan apayang harus dilakukan.

b. Memotivasi dengan bujukan (motivating by enticement)Yaitu dengan cara memotivas dengan bujukan atau memberi hadiahagar melakukan sesuatu sesuai harapan yang memberikan motivasi.

c. Memotivasi dengan identifikasi (motivating by identification)

Yaitu dengan cara memotivasi dengan menanamkan kesadaransehingga individu berbuat sesuatu karena adanya keinginan yangtimbul dari dalam dirinya sendiri dalam mencapai sesuatu.

Hakikat motivasi belajar menurut Uno (2009:23) adalah dorongan internal dan eksternal pada siswa-siswa yang sedang belajar untuk mengadakan perubahantingkah laku, pada umumnya dengan beberapa indikator atau unsur yang mendukung.Indikator motivasi belajar yang dijelaskan oleh Uno (2009:23) dapat diklasifikasikansebagai berikut:

a. Adanya hasrat dan keinginan berhasil.

b. Adanya dorongan dan kebutuhan dalam belajar. c. Adanya harapan dan cita-cita masa depan.

d. Adanya penghargaan dalam belajar.

e. Adanya kegiatan yang menarik dalam belajar.

f. Adanya lingkungan belajar yang kondusif, sehingga memungkinkan seseorangsiswa dapat belajar dengan baik.

\section{Gaya Belajar}

Gaya belajar adalah kunci untuk mengembangkan kinerja dalam pekerjaan, di sekolah, dan dalam situasi-situasi antar pribadi. Ketika menyadari bahwa bagaimana seseorang menyerap dan mengolah informasi, belajar dan berkomunikasi menjadi sesuatu yang mudah dan menyenangkan(Nunan, 1991: 168).Gaya belajar dapat didefinisikan sebagai usaha yang dilakukan individu untuk mencapai tujuan belajarnya. Sebagai langkah awal pengalaman belajar adalah mengenal gaya belajar. Menurut Bobbi De Porter dan Mike Hirarcky dalam Quantum Learning (2002: 123) ada 3 macam gaya belajar yaitu: gaya belajar visual, auditorial dan kinestetik.

a. Gaya belajar visual

b. Gaya belajar auditorial.

c. Gaya belajar kinestetik

Berdasarkan penelitian Kolb terdapat empatjenis gaya belajar, yakni accomodator, diverger, assimilatordan converger

1. Gaya belajar accomodator/activist.Gaya belajar accomodator adalah gaya belajarseseorang yang lebih menyukai pengalaman(concentrate experience) dan aktif bereksperimen(active experimentation). Seseorang lebihmenyukai mendapatkan informasi dari feelingdan memrosesnya dengan cara memraktikkanatau melakukannya.

2. Gaya belajar diverger/refflector.Gaya belajar 
diverger adalah gaya belajar seseorangyang lebih menyukai pengalaman

(concentrateexperiencing) dan mengamati

(reflectiveobservation). Peserta didik diverger lebihmenyukai memperoleh informasi dengan feelingdan memrosesnya dengan cara melihat danmendengar.

3. Gaya belajar converger/pragmatis. Gaya belajar converger adalah gaya belajarseseorang yang lebih menyukai sesuatu yangabstrak (abstract conceptualization) dan aktifbereksperimen (active experimentation). Pesertadidik memperoleh informasi dengan caramemikirkan (thinking) dan kemudian melakukannya(doing)

4. Gaya belajar Assimilator/TheoristGaya belajar assimilator adalah gaya belajarseseorang yang lebih menyukai pada sesuatuyang abstrak (abstract conceptualization) danmengamati (reflective observation), yaitu gayabelajar seseorang yang menyukai belajar denganberfikir, melihat atau mendengar.

Pada MBTI, preferensi gaya belajar seseorang dibedakan menjadi empat dimensi, yaitu:

1. Extroversion $V s$ Introversion. Introvert menemukan kekuatan dalam inner world dari ide konsep dan abstraksi. Dalam memahami fenomena tipe pembelajar ini cenderung lebih banyak berfikir dibandingkan berbicara. Introvert leaner dalam mengembangkan kerangka kerja dengan cara menyatukan dan menghubungkan informasi yang mereka pelajari. Pengetahuan yang diperolehnya kemudian saling dihubungkan untuk melihat sesuatu tersebut secara menyeluruh. Kemudian extrovert learner menemukankekuatan pada benda dan orang. Mereka lebih suka berinteraksi dengan orang lain. Mereka lebih suka berbicara dibandingkan mendengarkan. Mereka dapat belajar dari pengajar yang lain. Secara umum mereka tidak dapat memahami pelajaran sampai mereka dapat menjelaskan pada diri mereka sendiri atau pada orang lain (bekerja kelompok). Problem based Learning dan collaborative learning cocok untuk model pembelajaran.

2. Sensing $V s$ Intuition. Sensing learner adalah pembelajar yang lebih menyukai belajar dengan menggunakan kelima panca indra mereka. Mereka lebih menyukai sesuatu dengan rinci dan menginginkan fakta. Mereka lebih menyukai segala sesuatu ditata dengan teratur, pengajaran dilakukan secara terstruktur tahap demi tahap. Berbeda dengan Intuitive learner, mereka adalah pembelajar yang lebih menyukai berimajinasi dan berinovasi.

3. Thinking Vs Feeling. Thinking learner adalah pembelajar yang dalam memutuskan sesuatu berdasarkan pada analisis, logika dan prinsip. Dengan kata lain mereka dalam melihat sesuatu lebih kritis dan obyektif. Berbeda dengan feeling learner mereka lebih menggunakan pertimbangan nilai-nilai kemanusiaan (human values) dalam pengambilan keputusan. Mereka cenderung menjaga keharmonisan hubungan sosial dalam suatu kelompok. Mereka lebih menyukai bekerja dalam kelompok kecil.

4. Judging Vs Perceptive. Judging learner adalah pembelajar yang cenderung melakukan semua 
tugas lebih cepat dari batas waktu yang ditentukan. Mereka menyukai tips atau panduan bagaimana cara mengerjakan sesuatu dengan cepat. Berbeda dengan perceptive learner, mereka cenderung menunda tugas sampai menjelang batas akhir waktu yang ditentukan.

\section{Kemandirian Belajar}

Kemandirian belajar menurut Wayne $\mathrm{H}$ adalah menekankan sisi - sisi menguntungkan dari usaha bekerja secara kreatif atas prakarsanya sendiri, inisiatif dan panjang akal dari keadaan mempelajari suatu bidang secara intensif, pengembangan disiplin diri, dan belajar teknik-teknik didalam suatu bidang yang telah dipilihnya sendiri (Kartadinata, 2001).

Kemandirian belajar menurut Wragg E.C adalah suatu proses dimana mahasiswa mengembangkan keterampilan-keterampilan penting yang memungkinkannya menjadi pelajar yang mandiri, mahasiswa dimotivasi oleh tujuannya sendiri, imbalan dari proses belajar bersifat intrinsik atau nyata bagi mahasiswa dan tidak tergantung sistem luar untuk pemberian imbalan jerih payah belajarnya, dosen hanya merupakan sumber dalam proses belajar, tetapi bukan pengatur atau pengendali (Kartadinata, 2001).

Dalam sintesis kemandirian belajar terdapat dimensi pengelolaan belajar, tanggung jawab,dan pemanfaatan berbagai sumber belajar, sebagai berikut (dalam Izhar dan Encang).

1. Dimensi pengelolaan belajar berarti peserta ajar harus mampu mengatur strategi, waktu, dan tempat untuk melakukan aktivitas belajarnya seperti membaca, meringkas, membuat catatan dan mendengarkan materi dari audio. Pengelolaan belajar itu sangat penting. Peserta ajarlah yang secara otonom menentukan strategi belajar yang digunakan, kapan ia menggunakan waktu belajarnya, dan di mana ia melakukan proses pembelajarannya tanpa diperintah oleh orang lain. Kemampuan mengelola proses pembelajaran dapat membantu peserta ajar untuk berhasil dalam belajar.

2. Dimensi tanggung jawab berarti peserta ajar mampu menilai aktivitas, mengatasi kesulitan, dan mengukur kemampuan yang diperoleh dari belajar. Dalam belajar mandiri peserta ajar dituntut untuk memiliki kesiapan, keuletan, dan daya tahan. Sehingga diperlukan motivasi belajar yang tinggi. Kesulitan yang dialami dalam belajar harus mereka atasi sendiri dengan mendiskusikan sesama peserta ajar dengan memanfaatkan sumber belajar yang terkait dengan bahan ajar dan memperbanyak latihan soal yang dapat meningkatkan pemahaman peserta ajar. Disamping itu,peserta ajar harus mengukur kemampuan yang diperoleh dari hasil belajar bila hasil belajarnya tidak memuaskan dengan memperbaiki cara belajar dan secara rutin mengerjakan latihan soal.

3. Dimensi pemanfaatan berbagai sumber belajar berarti peserta ajar dapat menggunakan berbagai sumber belajar seperti modul, majalah, kaset audio, VCD, Computer Assested Instructional (CAI), internet, dan tutor. Peserta ajar secara leluasa menentukan pilihan sumber belajar yangdiinginkan. Kebebasan peserta ajar dalam memilih berbagai sumber belajar diharapkan dapat memperkaya pemahaman terhadap bahan ajar. 
Sedangkan kemandirian belajar menurut Sunaryo Kartadinata (2001) mempunyai 5 aspek dan dapat dijadikan indikator, antara lain :

1. Bebas bertanggung jawab dengan ciri-ciri mampu
4. Pengendalian diri, dengan ciri-ciri mampu mengendalikan emosi,mampu mengendalikan tindakan, menyukai penyelesaian masalahsecara damai, berpikir dulu sebelum bertindak dan

\begin{tabular}{|c|c|c|c|}
\hline \multicolumn{4}{|c|}{ Tabel 1. Kontribusi (Bobot) dan Masa Berlaku Nilai. } \\
\hline No. & Jenis Evaluasi Hasil Belajar & Masa Berlaku & Kontribusi* \\
\hline 1. & UAS Mata Kuliah & $1 \mathrm{smt}$ & Minimal $50 \%$ \\
\hline 2. & Ujian TAP & $1 \mathrm{smt}$ & Minimal $50 \%$ \\
\hline 3. & TTM Mata Kuliah & $2 \mathrm{smt}$ & $50 \%$ \\
\hline 4. & Tuton Mata Kuliah & $1 \mathrm{smt}$ & $30 \%$ \\
\hline 5. & $\begin{array}{l}\text { Praktikum Tatap Muka (PTM)/online } \\
\text { bagi EKSI }\end{array}$ & $1 \mathrm{smt}$ & $35 \%$ \\
\hline 6. & Tuton/ Bimbingan TAP non Pendas & $2 \mathrm{smt}$ & $50 \%$ \\
\hline 7. & TTM/Bimbingan TAP Pendas & $2 \mathrm{smt}$ & $50 \%$ \\
\hline 8. & $\begin{array}{l}\text { Praktek/Praktikum bagi MK } \\
\text { Berpraktek/Berpraktikum }\end{array}$ & $\begin{array}{l}\text { Selama menjadi mhs. } \\
\text { UT }\end{array}$ & $50 \%$ \\
\hline
\end{tabular}

menyelesaikantugas-tugas yang diberikan tanpa bantuan orang lain, tidak menundawaktu dalam mengerjakan tugas, mampu membuat keputusan sendiri,mampu menyelesaikan masalah sendiri dan bertanggung jawab ataumenerima resiko dari perbuatannya.

2. Progresif dan ulet, dengan ciri-ciri tidak mudah menyerah bilamenghadapi masalah, tekun dalam usaha mengejar prestasi,mempunyai usaha dalam mewujudkan harapannya, melakukanberbagai cara untuk mencapai tujuan dan menyukai hal-hal yangmenantang.

3. Inisiatif atau kreatif, dengan ciriciri mempunyai kreatifitas yangtinggi, mempunyai ide-ide yang cemerlang, menyukai hal-hal yangbaru, suka mencoba-coba dan tridak suka meniru orang lain.

mampumendisiplinkan diri.

5. Kemantapan diri, dengan ciri-ciri mengenal diri sendiri secaramendalam, dapat menerima diri sendiri, percaya pada kemampuansendiri, memperoleh kepuasan dari usaha sendiri dan tidak mudahterpengaruh oleh orang lain.

\section{Hasil Belajar Mahasiswa}

Berdasarkan Katalog UT Pendas

Dasar penilaian hasil belajar mahasiswa mengacu pada Surat Keputusan Rektor Nomor 3746/UN31/KEP/2013 tentang Perubahan Komposisi dan Bobot Penilaian Hasil Belajar bagi Mahasiswa Universitas Terbuka Tahun 2013, yaitu

1. Kontribusi (Bobot) dan Masa Berlaku Nilai Evaluasi Hasil Belajar

Setiap jenis evaluasi hasil belajar Program Sarjana dan Diplomamempunyai kontribusi (bobot) dan masa berlaku nilai sebagaimana tercantum pada Tabel 1 berikut.

\section{2.}

Komposisi Penilaian Hasil Belajar 
Program Sarjana dan Diploma adalah sebagai berikut.

a. Mata kuliah tidak berpraktek/berpraktikum dan tidak bertutorial, nilai hanya berasal dari UAS.

b. Mata kuliah tidak berpraktek/berpraktikum tetapi bertutorial, nilai berasal dari:

1) UAS;

2) Tugas dan partisipasi TTM atau tugas dan partisipasi Tuton (diambil nilai yang tertinggi).

Nilai pendukung (tutorial) akan berkontribusi terhadap nilai akhir mata kuliah, jika skor UAS $\geq 30$. Dengan demikian jika skor UAS < 30 nilai pendukung (tutorial) tidak akan berkontribusi terhadap nilai akhir mata kuliah, sehingga mahasiswa dinyatakan tidak lulus mata kuliah.

c. Mata kuliah berpraktek atau berpraktikum, nilai berasal dari:

1) UAS;

2) Praktek atau praktikum.

Untuk mata kuliah berpraktek atau berpraktikum, nilai tugas dan partisipasi TTM maupun Tuton tidak berkontribusi terhadap nilai akhir.

Nilai pendukung (praktek/praktikum) akan berkontribusi terhadap nilai akhir mata kuliah, jika skor UAS $\geq 30$. Dengan demikian jika skor UAS < 30 nilai pendukung (tutorial) tidak akan berkontribusi terhadap nilai akhir mata kuliah, sehingga mahasiswa dinyatakan tidak lulus mata kuliah.

d. Tugas Akhir Program (TAP), nilai berasal dari:
1) Ujian TAP;

2) Tugas dan partisipasi Tuton TAP (untuk program studi selain PGSD dan PGPAUD); Tugas dan partisipasi TTM TAP (untuk program Studi PGSD dan PGPAUD).

Nilai pendukung (tutorial) akan berkontribusi terhadap nilai akhir TAP, jika skor ujian TAP $\geq 30$. Dengan demikian jika skor ujian TAP < 30 nilai pendukung (tutorial) tidak akan berkontribusi terhadap nilai akhir TAP, sehingga mahasiswa dinyatakan tidak lulus TAP.

e. Mata kuliah khusus

Mata kuliah khusus diatur secara tersendiri oleh fakultas yang bersangkutan.

\section{Nilai TTM atau Tuton}

Bagi mahasiswa yang tidak berpartisipasi atau tidak memiliki nilai TTM atau Tuton, nilai akhir mata kuliah $100 \%$ dari nilai UAS. Apabila nilai TTM atau Tuton lebih rendah dari UAS, maka nilai TTM atau Tuton tersebut tidak diperhitungkan dalam penentuan nilai akhir mata kuliah, sehingga nilai akhir mata kuliah $100 \%$ dari nilai UAS.

4. Nilai Praktek/Praktikum/Tugas Jika praktek/praktikum/tugas merupakan kegiatan yang wajib, maka nilai akhir mata kuliah belum dapat diterbitkan apabila nilai yang diwajibkan tersebut belum ada di Pusat Pengujian. Nilai praktek dan praktikum bobotnya sesuai dengan ketentuan pada Tabel 2.1.

\section{Bentuk Nilai}

Nilai mahasiswa dinyatakan dalam bentuk huruf A, B, C, D, dan E. Nilai tersebut secara kualitatif dapat dilihat pada Tabel 2. 
Tabel 2. Bentuk Nilai

\begin{tabular}{|c|c|l|}
\hline Bentuk Nilai & Mutu & \multicolumn{1}{|c|}{ Keterangan } \\
\hline A & 4 & Sangat baik \\
\hline B & 3 & Baik \\
\hline C & 2 & Cukup \\
\hline D & 1 & Kurang \\
\hline E & 0 & Gagal/tidak lulus \\
\hline
\end{tabular}

\section{Nilai Ujian Setiap Semester}

Nilai mata kuliah setiap semester diumumkan dalam bentuk Daftar Nilai Ujian (DNU) yang dikirim oleh UPBJJUT kepada mahasiswa. DNU memuat nilai mata kuliah yang diikuti mahasiswa dalam satu semester.Dalam DNU terdapat informasi tentang Indeks Prestasi (IP) yaitu rata - rata nilai yang diperoleh tiap semester yang di tempuh

\section{HASIL PENELITIAN DAN PEMBAHASAN}

Penelitian ini menggunakan pendekatan cross sectional. Pada jenis ini variable independen dan dependen dinilai secara stimultan pada suatu saat, jadi tidak ada follow up. Tentunya tidak semua subyek penelitian harus di observasi pada hari atau pada waktu yang sama, akan tetapi dinilai hanya satu kali saja (Nursalam, 2003). Yang menjadi populasi target dalam penelitian ini adalah seluruh mahasiswa S1 PGSD masukan sarjana di UPBJJ UT Bandung dengan mengambil sampel di pokjar Kab. Kuningan yaitu sebanyak 162 Orang mahasiswa. Analisis Data untuk menganalisis pengaruh variable penelitian tersebut digunakan analisis jalur yang diestimasi dengan menggunakan bantuan aplikasi program Lisrel

\section{Hasil Belajar Mahasiswa S1 PGSD Masukan Sarjana Pokjar Kabupaten Kuninngan}

Tabel 3 berikut memaparkan hasil perolehan IPK hasil belajar mahasiswa.

Tabel 3. Perolehan IPK

\begin{tabular}{|c|c|c|c|}
\hline No & IPK & Jumlah & Persentase \\
\hline 1 & $2,00-2,50$ & 3 & $2 \%$ \\
\hline 2 & $2,51-3,00$ & 23 & $14 \%$ \\
\hline 3 & $3,10-3,50$ & 101 & $62 \%$ \\
\hline 4 & $3,51-4,00$ & 35 & $22 \%$ \\
\hline \multicolumn{2}{|c|}{ Jumlah } & 162 & $100 \%$ \\
\hline
\end{tabular}

Berdasarkan tabel diatas, mahasiswa S1 PGSD Masukan Sarjana di Kab Kuningan UPBJJ UT Bandung hampir di atas $50 \%$ mahasiswa memperoleh IPK di atas 3,1 yaitu sebesar $84 \%$ atau sebanyak 136 orang Hal ini menunjukan tingkat keberhasilan pembelajaran yang diterapkan oleh UT terhadap mahasiswa S1 PGSD masukan memperoleh hasil yang memuaskan.

Pengaruh Motivasi Belajar(X1), Gaya Belajar( $\left.\mathbf{X}_{2}\right)$, dan Kemandirian Belajar 
(X3) Terhadap Hasil Belajar Mahasiswa(Y)

\section{(1) Estimasi Koefisien Jalur}

Analisis ini meneliti tentang hubungan kausal pada model struktur yang terdiri dari 3 variabel bebas, yakni Motivasi Belajar $\left(\mathrm{X}_{1}\right)$, Gaya Belajar $\left(\mathrm{X}_{2}\right)$, dan Kemandirian Belajar $\left(\mathrm{X}_{3}\right)$ terhadap variabel terikat Hasil Belajar Mahasiswa (Y). Untuk menganalisis pengaruh tersebut digunakan analisis jalur yang diestimasi dengan menggunakan bantuan aplikasi program SPSS dan LISREL.

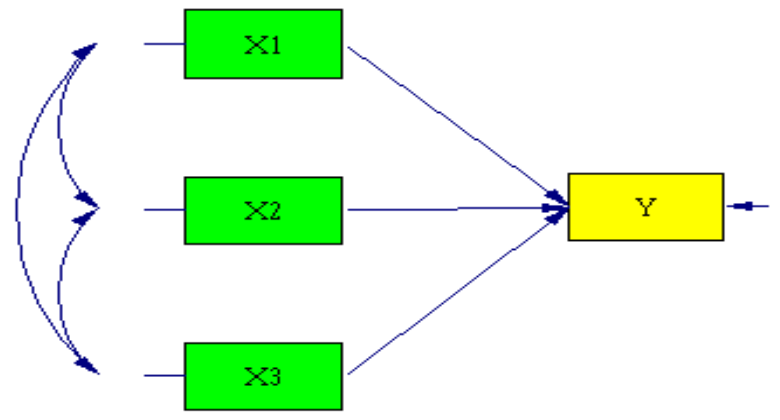

Gambar 1. Diagram Konseptual Analisis Jalur

Model jalur yang akan dicari untuk menjelaskan hubungan fungsional dari variabel Motivasi Belajar $\left(\mathrm{X}_{1}\right)$, Gaya Belajar $\left(\mathrm{X}_{2}\right)$, dan Kemandirian Belajar $\left(\mathrm{X}_{3}\right)$ terhadap variabel terikat Hasil Belajar Mahasiswa (Y) adalah sebagai berikut:

$$
\mathrm{Y}=\rho_{\mathrm{YX} 1} \mathrm{X}_{1}+\rho_{\mathrm{YX} 2} \mathrm{X}_{2}+\rho_{\mathrm{YX}} \mathrm{X}_{3}+\varepsilon_{1}
$$

Dimana:

$$
\mathrm{Y}=\text { Hasil Belajar Mahasiswa }
$$

$\mathrm{X}_{1}=$ Motivasi Belajar
$\mathrm{X}_{2}=$ Gaya Belajar

$\mathrm{X}_{3}=$ Kemandirian Belajar

$\varepsilon_{1}=$ Kontribusi variabel lain (epsilon)

$\rho_{Y X i}=$ Koefisien jalur dari $X$ ke- $\mathrm{i}$ terhadap $\mathrm{Y}, \mathrm{i}=1,2,3$

Dengan menggunakan bantuan aplikasi program SPSS diperoleh output hasil estimasi koefisien jalur sebagai berikut:

Tabel 4. Hasil Estimasi Koefisien Jalur

Coefficients

\begin{tabular}{|ll|r|r|r|r|r|}
\hline \multirow{2}{*}{ Model } & \multicolumn{2}{|c|}{$\begin{array}{c}\text { Unstandardized } \\
\text { Coefficients }\end{array}$} & $\begin{array}{c}\text { Standardized } \\
\text { Coefficients }\end{array}$ & & \\
\cline { 3 - 5 } & & \multicolumn{1}{|c|}{$\mathrm{B}$} & Std. Error & \multicolumn{1}{c|}{ Beta } & \multicolumn{1}{c|}{$\mathrm{t}$} & \multicolumn{1}{c|}{ Sig. } \\
\hline 1 & (Constant) & 1,657 &, 215 & & 7,701 &, 000 \\
& Motivasi Belajar (X1) &, 013 &, 003 &, 323 & 4,618 &, 000 \\
& Gaya Belajar (X2) &, 010 &, 003 &, 212 & 2,953 &, 004 \\
& Kemandirian Belajar (X3) &, 007 &, 002 &, 209 & 2,885 &, 004 \\
\hline
\end{tabular}

a. Dependent Variable: Hasil Belajar Mahasiswa (Y)

Berdasarkan output di atas diperoleh koefisien jalur untuk setiap variabel sebagai berikut:

$$
\begin{aligned}
& \rho_{Y X 1}=0,323 \\
& \rho_{Y X 2}=0,212 \\
& \rho_{Y X 3}=0,209 \\
& \text { Dengan demikian maka diperoleh }
\end{aligned}
$$
persamaan jalur sebagai berikut:

$$
\begin{aligned}
\mathrm{Y}= & 0,323 \mathrm{X}_{1}+0,212 \mathrm{X}_{2}+ \\
& 0,209 \mathrm{X}_{3}+\varepsilon_{1}
\end{aligned}
$$

Jika digambarkan, persamaan di atas tampak seperti hasil estimasi analisis jalur menggunakan bantuan aplikasi program LISREL yang disajikan melalui diagram berikut: 


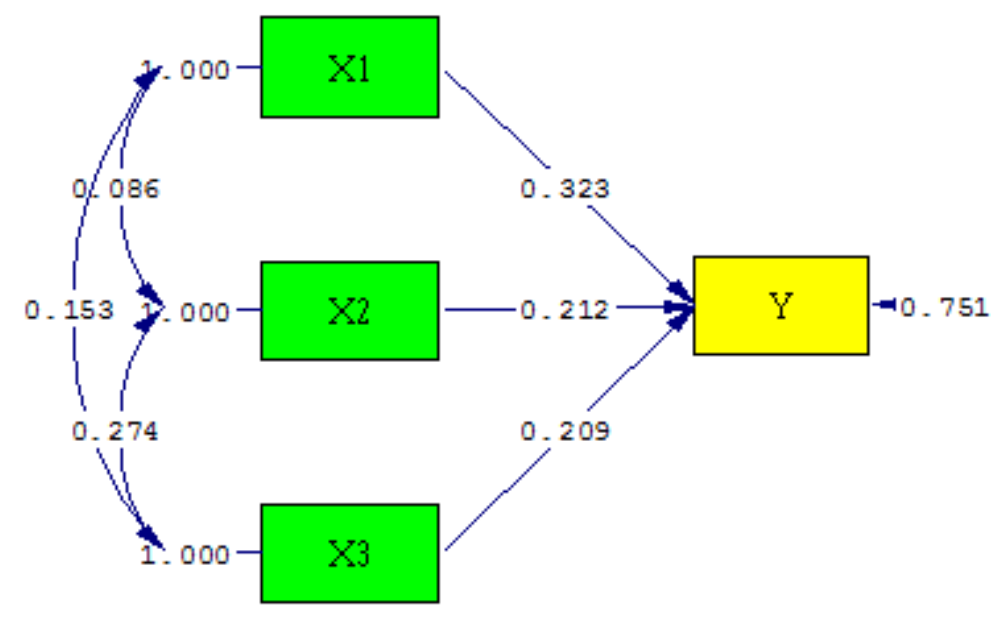

Gambar 2. Diagram Koefisien Jalur Sub Struktur 1

Nilai koefisien determinasi dan kontribusi variabel lain dapat diketahui melalui tabel berikut:

Tabel 5. Estimasi Koefisien Determinasi

\begin{tabular}{|l|l|l|l|c|}
\multicolumn{5}{c}{ Model Summary } \\
\hline Model & $\mathrm{R}$ & R Square & $\begin{array}{l}\text { Adjusted } \\
\text { R Square }\end{array}$ & $\begin{array}{c}\text { Std. Error of } \\
\text { the Estimate }\end{array}$ \\
\hline
\end{tabular}

Tabel 6. Hasil Estimasi Uji Hipotesis Simultan Sub Struktur 1

ANOVA

\begin{tabular}{|c|c|c|c|c|c|c|}
\hline Model & & $\begin{array}{l}\text { Sum of } \\
\text { Squares }\end{array}$ & $\mathrm{df}$ & Mean Square & $F$ & Sig. \\
\hline \multirow[t]{3}{*}{1} & Regression & 6,584 & 3 & 2,195 & 17,464 &, $000^{\mathrm{a}}$ \\
\hline & Residual & 19,855 & 158 & , 126 & & \\
\hline & Total & 26,439 & 161 & & & \\
\hline
\end{tabular}

a. Predictors: (Constant), Kemandirian Belajar (X3), Motivasi Belajar (X1), Gaya Belajar (X2)

b. Dependent Variable: Hasil Belajar Mahasiswa (Y)

Berdasarkan tabel di atas didapt nilai $R$-Square sebesar 0,249. Dengan demikian koefisien determinasi pengaruh Motivasi Belajar $\left(\mathrm{X}_{1}\right)$, Gaya Belajar $\left(\mathrm{X}_{2}\right)$, dan Kemandirian Belajar $\left(X_{3}\right)$ secara simultan terhadap variabel terikat Hasil Belajar Mahasiswa (Y) adalah sebesar $24,9 \%$, sedangkan sisanya sebesar $75,1 \%$ merupakan pengaruh dari variabel lain yang tidak diamati di dalam penelitian ini. (2) Uji Signifikansi Parameter
Untuk menguji pengaruh dari kedua variabel bebas terhadap variabel terikat yang dijelaskan oleh persamaan jalur di atas, berikut akan disajikan pengujian hipotesis baik secara simultan dengan menggunakan uji $\mathrm{F}$ maupun secara parsial dengan menggunakan uji $\mathrm{t}$.

- Uji Hipotesis Simultan (Uji F)

Hipotesis yang akan diuji adalah:

$\mathrm{H}_{0} \rightarrow \rho_{\mathrm{YXi}}=0 \quad$ Tidak terdapat pengaruh yang signifikan dari Motivasi Belajar $\left(\mathrm{X}_{1}\right)$, Gaya Belajar $\left(\mathrm{X}_{2}\right)$, dan 
Kemandirian Belajar $\left(\mathrm{X}_{3}\right)$ secara simultan terhadap Hasil Belajar Mahasiswa (Y);

$\begin{array}{ll}\mathrm{H}_{1} \rightarrow \rho_{\text {YXi }} \neq 0 & \begin{array}{l}\text { Terdapat } \\ \text { pengaruh yang }\end{array} \\ & \text { signifikan dari } \\ & \text { Motivasi Belajar } \\ & \left(\mathrm{X}_{1}\right), \quad \text { Gaya } \\ & \text { Belajar }\left(\mathrm{X}_{2}\right) \text {, dan } \\ & \text { Kemandirian } \\ & \text { Belajar }\left(\mathrm{X}_{3}\right) \\ \text { Berdasarkan } & \text { output di atas, }\end{array}$
diperoleh nilai $\mathrm{F}$ hitung sebesar 17,464. Nilai ini kemudian akan dibandingkan dengan nilai $\mathrm{F}$ pada tabel distribusi $\mathrm{F}$. Untuk $\alpha=5 \%, \mathrm{db}_{1}$ (derajat bebas) $=\mathrm{k}=3$, dan $\mathrm{db}_{2}=\mathrm{n}-\mathrm{k}-1=162-3-1=158$ diperoleh nilai $\mathrm{F}$ tabel sebesar 2,662. secara simultan terhadap Hasil

Belajar

Mahasiswa (Y);

Tingkat signifikansi $\alpha=5 \%$.

Statistik uji yang digunakan adalah $\mathrm{F}$.

Dengan menggunakan bantuan aplikasi program SPSS diperoleh nilai statistik F sebagai berikut:

Kriteria uji:

Tolak $\mathrm{H}_{0}$ dan terima $\mathrm{H}_{1}$ jika $\mathrm{F}$ hitung $\geq$ F tabel; atau

Terima $\mathrm{H}_{0}$ dan tolak $\mathrm{H}_{1}$ jika $\mathrm{F}$ hitung $<\mathrm{F}$ tabel.

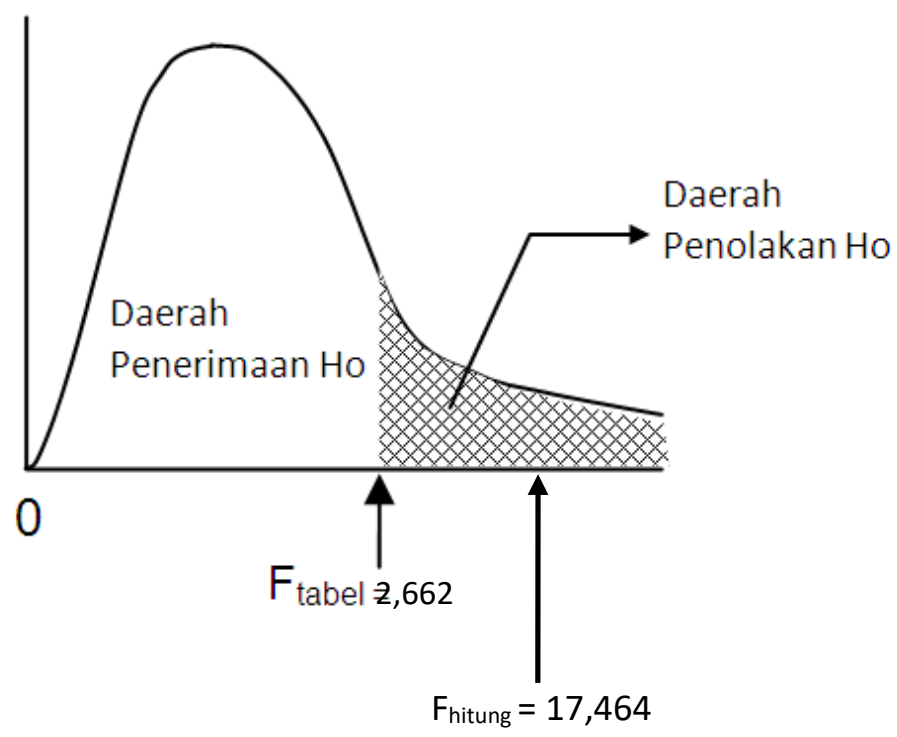

\section{Gambar 3. Kurva Pengujian Hipotesis Simultan Sub Struktur 1}

Dikarenakan F hitung $(17,464)>\mathrm{F}$ tabel $(2,662)$ maka $\mathrm{H}_{0}$ ditolak dan $\mathrm{H}_{1}$ diterima, artinya bahwa Motivasi Belajar $\left(\mathrm{X}_{1}\right)$, Gaya Belajar $\left(\mathrm{X}_{2}\right)$, dan Kemandirian Belajar $\left(\mathrm{X}_{3}\right)$ secara simultan berpengaruh signifikan terhadap Hasil Belajar Mahasiswa (Y).

\section{Uji Hipotesis Parsial (Uji t)}

Hipotesis yang akan diuji adalah:

1) $\quad \mathrm{H}_{0} \rightarrow \rho_{\mathrm{YX} 1}=0$ Motivasi Belajar

$\left(\mathrm{X}_{1}\right)$ tidak berpengaruh signifikan secara parsial terhadap Hasil Belajar Mahasiswa (Y);

$\mathrm{H}_{1} \rightarrow \rho_{\mathrm{YX} 1} \neq 0 \quad$ Motivasi

Belajar $\quad\left(\mathrm{X}_{1}\right) \quad$ berpengaruh signifikan secara parsial terhadap Hasil Belajar Mahasiswa (Y).

2) $\mathrm{H}_{0} \rightarrow \rho_{\mathrm{YX} 2}=0$ Gaya Belajar $\left(\mathrm{X}_{2}\right)$ tidak berpengaruh signifikan secara parsial terhadap Hasil Belajar Mahasiswa (Y); 
$\mathrm{H}_{1} \rightarrow \rho_{\mathrm{YX} 2} \neq 0 \quad$ Gaya

Belajar $\quad\left(\mathrm{X}_{2}\right) \quad$ berpengaruh signifikan secara parsial terhadap Hasil Belajar Mahasiswa (Y).

3) $\mathrm{H}_{0} \rightarrow \rho_{\mathrm{YX} 3}=0$ Kemandirian Belajar $\left(\mathrm{X}_{3}\right)$ tidak berpengaruh signifikan secara parsial terhadap Hasil Belajar Mahasiswa (Y);

$\mathrm{H}_{1} \rightarrow \rho_{\mathrm{YX} 3} \neq 0$ Kemandirian Belajar $\quad\left(\mathrm{X}_{3}\right)$ berpengaruh signifikan secara parsial terhadap Hasil Belajar Mahasiswa (Y).

Tingkat signifikansi $\alpha=5 \%$.

Statistik uji yang digunakan adalah $\mathrm{t}$

Dengan menggunakan bantuan aplikasi program SPSS, diperoleh nilai statistik t sebagai berikut:

\section{Tabel 7. Hasil Estimasi Uji Hipotesis Parsial}

\begin{tabular}{|ll|r|r|r|r|r|}
\hline \multicolumn{1}{|c|}{ Coefficients $^{2}$} \\
Model & \multicolumn{2}{|c|}{$\begin{array}{c}\text { Unstandardized } \\
\text { Coefficients }\end{array}$} & $\begin{array}{c}\text { Standardized } \\
\text { Coefficients }\end{array}$ & & \\
\cline { 2 - 5 } & & \multicolumn{1}{c|}{ B } & Std. Error & Beta & t & Sig. \\
\hline 1 & (Constant) & 1,657 &, 215 & & 7,701 &, 000 \\
& Motivasi Belajar (X1) &, 013 &, 003 &, 323 & 4,618 &, 000 \\
& Gaya Belajar (X2) &, 010 &, 003 &, 212 & 2,953 &, 004 \\
& Kemandirian Belajar (X3) &, 007 &, 002 &, 209 & 2,885 &, 004 \\
\hline
\end{tabular}

a. Dependent Variable: Hasil Belaiar Mahasiswa $(Y)$

Berdasarkan output di atas, diperoleh nilai t hitung untuk $\mathrm{X}_{1}$ sebesar $4,168, X_{2}$ sebesar 2,953, dan t hitung untuk $\mathrm{X}_{3}$ sebesar 2,885. Nilai ini kemudian akan dibandingkan dengan nilai t pada tabel distribusi t. Untuk $\alpha=5 \%$, db $($ derajat bebas $)=n-k-1=162-3-1=158$ untuk pengujian dua sisi diperoleh nilai $\mathrm{t}$ tabel sebesar 1,975.

Kriteria uji:

Tolak $\mathrm{H}_{0}$ dan terima $\mathrm{H}_{1}$ jika $-\mathrm{t}$ tabel $\geq \mathrm{t}$ hitung $\geq \mathrm{t}$ tabel; atau

Terima $\mathrm{H}_{0}$ dan tolak $\mathrm{H}_{1}$ jika -t tabel $<\mathrm{t}$ hitung $<\mathrm{t}$ tabel.

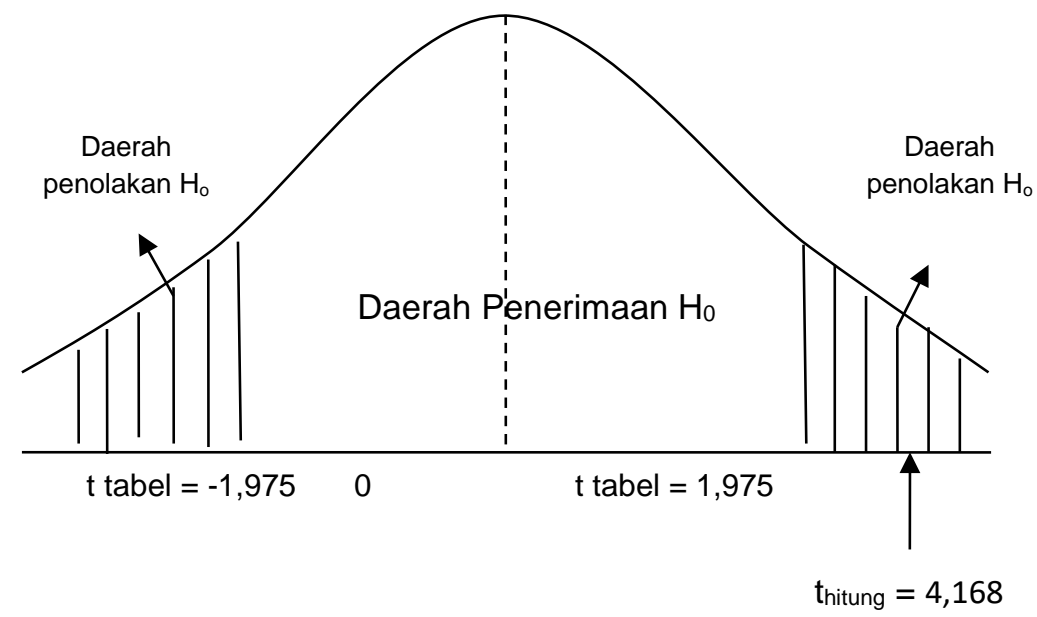

\section{Gambar 4. Kurva Pengujian Hipotesis Parsial Pengaruh $X_{1}$ terhadap Y}

Berdasarkan kriteria uji yang telah dipaparkan sebelumnya, maka t hitung $(4,168)>\mathrm{t}$ tabel $(1,975)$ mengindikasikan bahwa $\mathrm{H}_{0}$ ditolak dan $\mathrm{H}_{1}$ diterima, artinya
Motivasi Belajar $\left(\mathrm{X}_{1}\right)$ berpengaruh signifikan secara parsial terhadap Hasil Belajar Mahasiswa (Y). 


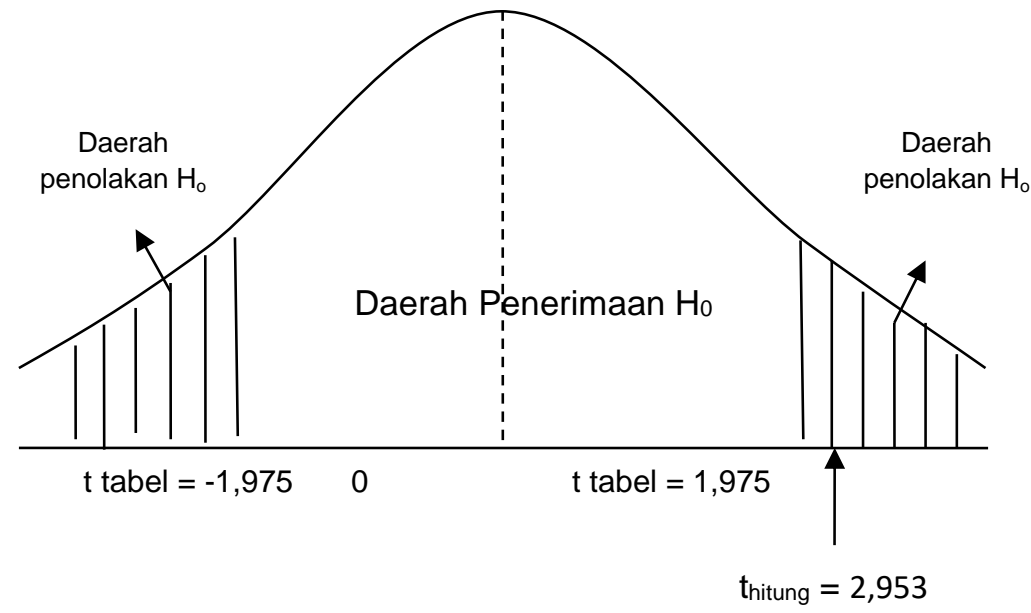

\section{Gambar 5. Kurva Pengujian Hipotesis Parsial Pengaruh $X_{2}$ terhadap Y}

Berdasarkan kriteria uji yang telah Gaya Belajar $\left(\mathrm{X}_{2}\right)$ berpengaruh signifikan dipaparkan sebelumnya, maka t hitung secara parsial terhadap Hasil Belajar $(2,953)>\mathrm{t}$ tabel $(1,975)$ mengindikasikan Mahasiswa (Y).

bahwa $\mathrm{H}_{0}$ ditolak dan $\mathrm{H}_{1}$ diterima, artinya

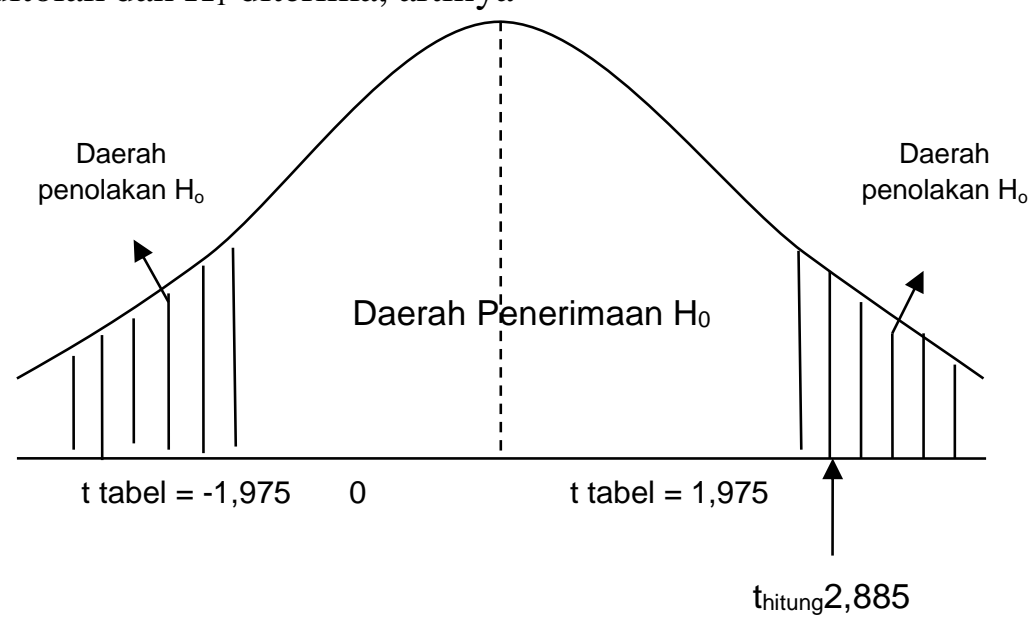

\section{Gambar 6. Kurva Pengujian Hipotesis Parsial Pengaruh $X_{3}$ terhadap Y}

Berdasarkan kriteria uji yang telah dipaparkan sebelumnya, thitung $(2,885)>$ $\mathrm{t}$ tabel $(1,975)$ mengindikasikan bahwa $\mathrm{H}_{0}$ ditolak dan $\mathrm{H}_{1}$ diterima, artinya Kemandirian Belajar $\left(\mathrm{X}_{3}\right)$ berpengaruh signifikan secara parsial terhadap Kemandirian Belajar (Y).

(3) Analisis Pengaruh Langsung dan Pengaruh Tidak Langsung
Untuk melihat lebih detail tentang besar pengaruh langsung dan tidak langsung dari masing-masing variabel bebas terhadap variabel terikat, sehingga secara statistik dinyatakan berpengaruh atau tidak berpengaruh, berikut disajikan rincian pengaruh langsung dan tidak langsungnya. 
Tabel 8. Hasil Estimasi Pengaruh Langsung dan Pengaruh Tidak Langsung

\begin{tabular}{|c|c|c|c|c|c|c|c|}
\hline \multirow{2}{*}{ Variabel } & \multirow{2}{*}{$\begin{array}{c}\text { Koefisien } \\
\text { Jalur }\end{array}$} & \multirow{2}{*}{$\begin{array}{l}\text { Pengaruh } \\
\text { Langsung }\end{array}$} & \multicolumn{3}{|c|}{$\begin{array}{l}\text { Pengaruh tidak } \\
\text { langsung melalui: }\end{array}$} & \multirow{2}{*}{$\begin{array}{c}\text { Pengaruh } \\
\text { Tidak } \\
\text { Langsung }\end{array}$} & \multirow{2}{*}{$\begin{array}{c}\text { Total } \\
\text { Pengaruh }\end{array}$} \\
\hline & & & $\mathbf{X 1}$ & $\mathbf{X} 2$ & $\mathbf{X 3}$ & & \\
\hline $\mathrm{X} 1$ & 0,323 & $10,4 \%$ & - & $0,6 \%$ & $1,0 \%$ & $1,6 \%$ & $12,0 \%$ \\
\hline $\mathrm{X} 2$ & 0,212 & $4,5 \%$ & $0,6 \%$ & - & $1,2 \%$ & $1,8 \%$ & $6,3 \%$ \\
\hline X3 & 0,209 & $4,4 \%$ & $1,0 \%$ & $1,2 \%$ & - & $2,2 \%$ & $6,6 \%$ \\
\hline \multicolumn{7}{|c|}{ Total Pengaruh } & $24,9 \%$ \\
\hline
\end{tabular}

- Motivasi Belajar $\left(\mathrm{X}_{1}\right)$ berpengaruh signifikan terhadap Hasil Belajar Mahasiswa (Y) sebagaimana telah di sajikan pada uji-t dengan total pengaruh sebesar $12,0 \%$, terdiri atas pengaruh langsung sebesar $10,4 \%$ dan pengaruh tidak langsung sebesar $1,6 \%$.

- Gaya Belajar $\left(\mathrm{X}_{2}\right)$ berpengaruh signifikan terhadap Hasil Belajar Mahasiswa (Y) sebagaimana telah di sajikan pada uji-t dengan total pengaruh sebesar $6,3 \%$, terdiri atas pengaruh langsung sebesar $4,5 \%$ dan pengaruh tidak langsung sebesar $1,8 \%$.

- Kemandirian Belajar $\left(\mathrm{X}_{3}\right)$ berpengaruh signifikan terhadap Hasil Belajar Mahasiswa (Y) sebagaimana telah di sajikan pada uji-t dengan total pengaruh sebesar $6,6 \%$, terdiri atas pengaruh langsung sebesar $4,4 \%$ dan pengaruh tidak langsung sebesar $2,2 \%$.

Dengan demikian, total pengaruh pengaruh Motivasi Belajar $\left(\mathrm{X}_{1}\right)$, Gaya Belajar $\left(\mathrm{X}_{2}\right)$, dan Kemandirian Belajar $\left(X_{3}\right)$ secara bersama-sama terhadap variabel Hasil Belajar Mahasiswa (Y) adalah sebesar $24,9 \%$, sedangkan sisanya sebesar $75,1 \%$ merupakan pengaruh dari variabel lain yang tidak diamati di dalam penelitian ini.

\section{KESIMPULAN}

Hasil belajar mahasiswa S1 PGSD Masukan Sarjana di Kab. Kuningan UPBJJ UT Bandung yaitu perolehan IPK menunjukkan hasil yang baik. Sehingga dapat di simpulkan para mahasiswa tidak memiliki kendala ketika mengikuti sistem pembelajaran yang di terapkan oleh UT.Motivasi belajar, gayabelajar, dan kemandirian belajar berpengaruh terhadap hasil belajar mahasiswa dimana pengaruh masing - masing variabel sangat kecil. Pengaruh motivasi belajar lebih besar dibandingkan dengan gaya belajar dan kemandirian belajar.

\section{DAFTAR PUSTAKA}

Arikunto, S. (2003).Manajemen penelitian. Cetakan VI. Jakarta: PT RinekaCipta

Canfield, A., and W. Knight. 1983. Learning Style Inventory. Los Angeles. CA: Western Psycological Services

Darmayanti, T., Islam, S., \& Asandhimitra. (2004). Pendidikan tinggi jarak jauh: Kemandirian belajar pada PTJJ. Jakarta: Pusat Penerbitan Universitas Terbuka.

Diminarni, Puspitasari. 2010. "Pengaruh Motivasi Belajar, Gaya Belajar dan Berfikir Kritis Terhadap Indeks 
Prestasi Kumulatif', Skripsi, Jawa Timur, Universitas Pembangunan Nasional veteran

DePorter B, Reardon M, \& Nourie Singer S. 2007. Quantum TeachingMempraktikkan Quantum Learning di Ruang-ruang Kelas. Bandung: Kaifa

DePorter B \& Hernacki M. 2010.Quantum Learning Membiasakan Belajar Nyaman dan Menyenangkan. Bandung: Kaifa

Haryono, A. (2001). Belajar mandiri konsep dan penerapannya dalam sistem pendidikan dan pelatihan terbuka/jarak jauh.Jurnal Pendidikan Terbuka dan Jarak Jauh, 2(2 ), hal. 137-161. Jakarta: Universitas Terbuka.

Hickocx, L.K. 1995. Learning styles: A survey of adult learning style inventory models. In R. R. Sims \& S. J. Sims (Eds).The importance of learning styles: Understanding the implications for learning, course design, andeducation. Wesport, CT: Grenworod Press.

Irzan Tahar dan Enceng (2006). Hubungan Kemandirian Belajar Dan Hasil Belajar Pada Pendidikan Jarak Jauh Jurnal Pendidikan Terbuka dan Jarak Jauh, Volume. 7, Nomor 2, September 2006, 91-101

Kartadinata, S. (2001).Kemandirian belajar dan orientasi nilai mahasiswa.Bandung : PPS.
Knowles, M.S. (1975). Self directed learning, a guide for leaners and teachers. Englewood Cliffs: Prentice Hall Regents.

Kolb.D.A. 1985.Learning Style Inventory Self Scoring Inventory and Interpretation Buuklt. Boston, NA:MCBER and Company.

Long, H.B. (1989).Self-directed learning: Emerging theory \& practice. USA: Oklahoma ResearchCenter.

Sugilar.(2000). Kesiapan belajar mandiri peserta pendidikan jarak jauh.Jurnal Pendidikan Terbuka

dan Jarak Jauh, 1(2), hal. 13. Jakarta: Universitas Terbuka.

Suparman, A. \& Zuhairi, A. (2009). Pendidikan Jarak Jauh, Teori dan Praktek. Jakarta: Pusat Penerbitan Universitas Terbuka

Sugiyono, 2012.Metode Penelitian Kuantitatif, Kualitatif Dan R \& D. Bandung: Alfabeta.

Susanti, R. D \& Nadziruddin, Udin (2007). Faktor Internal Yang Berkontribusi Terhadap Pencapaian Indeks Prestasi Kumulatif Pada Mahasiswa Program A Fik Unpad. Abstrak.

Uno H B. 2009. Model Pembelajaran Menciptakan Proses Belajar Mengajar yang Kreatif dan Efektif. Pontianak: Sinar Grafika Offset 